\title{
YELLOW KRANG - A NEW CULTIVAR OF PAPAYA FOR GREEN CONSUMPTION WITH TOLERANCE TO PAPAYA RINGSPOT VIRUS
}

\author{
Rapatsa JANTHASRI*, Wiwat CHAIYABOON \\ Rajabhat Maha Sarakham University, Muang Maha Sarakham 44000, Thailand \\ Received: August 2015; Accepted: November 2015 \\ Edited by: E. Żurawicz
}

\begin{abstract}
The development of a papaya cultivar for unripe or green consumption that has resistance to papaya ringspot virus (PRSV) began in 2004 by crossing red-fleshed 'Red Krang' cultivar with yellow-fleshed Sai Nampeung cultivar. Numerous diverse hybrids that were obtained were selected in a recurrent selection until 2010. The 'Yellow Krang' line was selected because of the early and high yielding, elongated fruit shape, is yellow and crispy flesh when unripe and suitable for consumption as green papaya, and tolerance to PRSV. From 2010 to 2015 the 'Yellow Krang' line was refined through pure line selection. It was evaluated in four growing areas in Thailand for 3 years. The field trial showed that 'Yellow Krang' can be classified as dwarf, reaching a height of $110-150 \mathrm{~cm}$, early bearing, with mean 105 days to first flower anthesis; an average of 100 flowers and 206 fruits per plant, mean fruit weight $1.2 \mathrm{~kg}$, mean fruit thickness $2.4 \mathrm{~cm}$, mean fruit firmness 7.15 Newtons; high yielding, with mean fresh weight yield of $134.606 \mathrm{~kg} / \mathrm{hec}-$ tare; and $24.86 \%$ incidence of PRSV.
\end{abstract}

Key words: Carica papaya, conventional breeding, hybridization, pure line selection, selection cycle, field comparative trials, Thailand

\section{INTRODUCTION}

At present, demand for papaya in the domestic market is rising considerably, including demand for fruit to consume green, for eating fresh, for processing into canned fruit, in chili and tomato sauce, for the leather tanning industry, the textile industry and for tenderizing in the canned meat and fish industry (Janthasri 2007). Green papaya is an especially important ingredient that is essential for making the perennially popular everyday dish "som tam", or raw papaya salad. Consumers in northeastern Thailand are particularly fond of som tam, so there is very high demand for green papaya in this region. However, papaya production has dropped due to the outbreak of papaya ringspot virus (PRSV) (Janthasri 2004). PRSV is especially dangerous because it is very difficult to detect in its early stages and by the time when the symptoms are noticeable, the infection is severe. It also spreads very quickly.
Now, PRSV has affected papaya growers in every region of the country, and even papaya plants grown casually by backyard gardeners are affected. Thailand's Department of Agriculture has tested several methods to combat PRSV using chemicals, eradication and cross-protection (Somsri 2014) but so far no effective method has yet been discovered to prevent or control the disease. PRSV causes the fruit quality to drop significantly or even causes the plants to fully stop bearing fruit completely. Once PRSV has infected an area, it tends to be persistent and any new papaya seedlings grown in the same area will get the disease (Janthasri \& Janthasri 2005). The PRSV outbreak has caused overall papaya production in Thailand to drop, and has impacted the industries that use papaya as a raw material.

Most of the research on papaya in Thailand has focused on breeding to develop cultivars that are resistant to PRSV and have high yield and fruit quality. This kind of work takes a long time, and some 
new cultivars are tested and developed for 1520 years before they can be released to farmers. Since papaya is naturally open pollinating, if controls are not used to prevent outcrossing, then most cultivars will naturally hybridize and gradually lose their disease tolerance. At present there are several cultivars of papaya in Thailand, but none of them are sufficiently tolerant to PRSV. In the USA transgenic papaya had been developed that has good PRSV resistance (Drew 2014), and in collaborative work with Cornell University, researchers in Thailand also developed a transgenic papaya suitable for Thailand using the same coat protein gene (Somsri 2014), but unfortunately the Thai government does not presently permit the growing of genetically modified crops. New cultivars have been developed through conventional breeding and recommended to farmers, but most of them are not adapted to the growing area in northeast Thailand.

The objective of this research was to develop a papaya cultivar for green consumption that would be tolerant to PRSV.

\section{MATERIALS AND METHODS}

\section{Hybridization of the parental cultivars and han- dling of seedlings}

Two papaya cultivars were chosen as the parents - 'Red Krang' and 'Sai Nampheung'. 'Red Krang' is a red-fleshed cultivar, widely grown for unripe consumption in Thailand. It is monoecious with male, female and hermaphrodite flowers in different proportions on different plants. The fruits are elongated, weighing on average $1.8-2.1 \mathrm{~kg}$. When unripe, the flesh is dense and crispy, appropriate for making som tam. When ripe, the flesh is red, sweet and aromatic. The cultivar has a certain degree of PRSV tolerance, but its disadvantage is that the outside surface of the fruit is grooved. The cultivar Sai Nampheung is now very rare in Thailand. It is also monoecious and the trees have male, female and hermaphrodite flowers. The fruits are mediumsized, weighing on average 0.7-1.2 $\mathrm{kg}$, with a smooth surface. When unripe, the flesh is orangeyellow and when ripe it is golden yellow, sweet and aromatic. This cultivar is susceptible to PRSV.
The two parent cultivars were reciprocally pollinated using 30 hermaphrodite flowers as female and pollen from 30 male flowers as male from each cultivar. From obtained $20 \mathrm{~F}_{1}$ hybrid seedlings 1482 $\mathrm{F}_{2}$ hybrid plants were grown. Selection was made for the desired traits: medium-sized fruits (0.8$1.2 \mathrm{~kg}$ ) with smooth peel (easy to grate) and flesh that is crispy when unripe. As crispiness is the most desirable quality for unripe papaya, the fruits were judged for crispiness rather than taste. The other major trait that was selected was genetically determined quantitative tolerance to PRSV that can be stably inherited (Litz \& Conover 1981). Disease tolerance can be enhanced by recurrent selection, so seeds from the fruit of the $\mathrm{F}_{2}$ hybrids were taken for further testing. They were immersed in $50{ }^{\circ} \mathrm{C}$ water for 24 hours and those that floated were discarded. The remainder were wrapped in a moist cloth and placed in a tightly sealed plastic bag and kept in the shade for 3-5 days. When the emerging white radical was clearly visible, the seeds were planted in black plastic $2 \times 6$ inch bags filled with a planting medium consisting of topsoil: burnt rice husks: manure at a ratio of $2: 3: 1$ that had been treated with calcium oxide and metalaxyl ( $30 \mathrm{~g}$ in 201 of water) to kill fungus and prevent damping off. The seedlings were planted at a spacing of $3 \times 3 \mathrm{~m}$, two seedlings in each hole. The plants were fertilized and watered in a manner typical of this plant. When necessary, chemicals were used at the recommended dosage to treat insect pests and diseases, such as carbosulfan for thrips and benomyl for anthracnose. The following data were collected: date of the first flowering, date of the first fruit set and number of fruits per plant. Three unripe green fruits (about 2 months old) were randomly selected per plant and the fresh fruit weight was measured. Flesh thickness was measured at the thickest and thinnest portions when the fruit was cut lengthwise and the two values were averaged. Fruit firmness was measured using a firmness tester (Effegi, Italy).

\section{Progeny testing}

Five cycles of progeny testing were done from 2005 to 2010, using randomized complete block design (RCBD) containing five replications with 
10 plants per replication. The experiments were performed at the test fields of the Papaya Research and Development Centers in Maha Sarakham, Kalasin, Roi Et and Khon Kaen Provinces. In the fifth cycle, three lines were selected for green papaya consumption, designated 2-8, 2-10 and 2-15. These lines were derived from seeds of 3 fruits from the best selected plant in the final selection (B9R4T2, or Block 9, Row 4, Tree 2) (Fig. 1). Data were collected on growth rate (date of first flower bloom and number of flowers per tree at 4 months) and on the quality of unripe fruits. Three unripe green fruits (about 2 months old) were randomly selected per tree. The number of fruits per tree was recorded at 8 months, along with fruit weight, flesh thickness and firmness.

Level of infestation by PRSV was evaluated using a five-point (0-4) rating scale as follows:

- Level 0 = no symptoms; very good tolerance;

- Level 1 = very mild mottling, meaning yellow areas covering $1-25 \%$ of the leaf area, with some ring spots on the leaves but no perceptible symptoms on the fruit, no bruises or streaks on petioles and stem; good tolerance;

- Level $2=$ mild to moderate mottling, meaning yellow areas covering $26-50 \%$ of the leaf area, fruit mostly smooth with some ring spots, no bruises or streaks on petioles or stem; medium tolerance;

- Level 3 = mottling, meaning yellow areas covering $51-75 \%$ of the leaf area, clear evidence of ring spots all over the fruit, and bruises or streaks on the petioles and stem; little tolerance;

- Level 4 = severe mottling, meaning yellow areas covering $75-100 \%$ of the leaf area, deformed or brittle leaves up to severe leaf distortion with only the midrib visible, clearly seen ring spots all over the fruit, scabby spots, deformed fruit, rough outer peel and bitter, grainy flesh; no tolerance (Prasartsee 2009).

\section{Pure line selection}

The 'Yellow Krang' line (Fig. 2) was further selected to improve consistency and uniformity of the desired traits, that is: early flowering (less than 115 days to first anthesis), elongated fruit shape, more than 100 fruits per tree, crispy flesh when unripe, and also the low level of incidence to PRSV (tested in the field). The pure line selection method was used starting with the first cycle in 2010 when 20 'Yellow Krang' line trees from the fifth cycle of recurrent selection (seeds from lines 2-8, 2-10 and 2-15) were selected and grown in rows consisting of 20 plants. At first, two seedlings were planted in each hole, and after they flowered, just one plant with hermaphrodite flowers was left. Data were collected on flowering and fruiting dates and quality as well as PRSV incidence using the 4-point scale. One tree was selected per row with the best of the following qualities: good growth rate, consistent flowering and fruit set, elongated fruit, more than 100 fruits per tree per year, firm, crispy fruit flesh when unripe, and a good level of PRSV tolerance. The flowers of the chosen trees were selfed and protected against cross-pollination and the seeds were collected for the next cycle. The same tree maintenance and selection methods were used for 5 cycles.

\section{Field trials of 'Yellow Krang' line}

In 2013-2015 the selected line 'Yellow Krang' was tested in field experiments located in four provinces: Maha Sarakham, Kalasin, Roi Et and Khon Kaen. 'Red Krang', 'Khaeg Dum Gosum', and 'Khaeg Nuan' were the check cultivars. The field trials were designed in RCBD with four cultivars There were 20 plants per cultivar (5 replications (plots) with 4 plants per plot. The planting and care were the same as stated previously. Data were collected on growth rate (date of first flower anthesis, number of flowers at 4 th months, number of fruits grown to harvest maturity at 8th month), fruit yield, fruit quality (fruit weight, flesh color, flesh firmness, and flesh thickness), incidence of PRSV and level of infection symptoms.

\section{Statistical analysis}

Data of field experiment aiming comparison of new cultivar with three check cultivars were analyzed using one way ANOVA and LSD test at $\alpha=0.05$. Data were collected for 3 years and averaged before comparing the data of each cultivar in each growing area. Calculations were done by using MSTAT software (Bricker 1989). 


\section{RESULTS}

\section{Hybridization, selection and testing of PRSV-tol- erant 'Yellow Krang' papaya}

Reciprocal crossing of 'Red Krang' with 'Sai Nampeung' by hand pollination made in 2004-2005 resulted in $20 \mathrm{~F}_{1}$ hybrids. From the seeds of these hybrids, 1482 papaya plants were grown. The general observations were that the hybrid plants with 'Red Krang' as male parent tended to have longer fruits and more orange flesh, while those with 'Sai Nampeung' as male parent tended to be taller, with greater PRSV resistance, and had more yellow fruits and more fragrant ones (data not shown). Out of the $1482 \mathrm{~F}_{2}$ hybrids, two plants (No. 60 and No. 80) were selected on the base of desired traits: early flowering (about 100 days), high yield (about 100 fruits per tree), elongated fruit shape, good flavor and crispness of unripe fruit, thick flesh, small seed cavity and tolerance to PRSV (Fig. 1). In the second cycle, 994 plants from the seeds obtained from two above plants were grown. All the plants derived from No. 60 did not have good PRSV tolerance and were discarded, but one plant from No. 80 was selected for possessing the desired traits. In the third cycle, 448 plants were grown from seeds of above plant and two plants were selected from which, in the fourth cycle, 589 plants were grown and one plant was selected. In the fifth cycle, 972 plants were grown from the seeds of three fruits and three plants from one fruit were selected. Three plants of above progeny had very similar levels of the desired characteristics. The seeds from the fruit of these three plants were collected and bulked as the cultivar 'Yellow Krang'.

In years 2010-2015 from the population of 'Yellow Krang', one pure line based on the criteria outlined above was selected (Fig. 2). Seedlings of this were used for field trials.

\section{Field trials of 'Yellow Krang' (RMU 1) Flowering and fruiting}

There were statistically significant differences in number of days to flowering and number of flowers per tree (at the age of 4 months) between the different cultivars in all the four study areas. 'Yellow Krang' flowered earlier than the check cultivars although no statistical difference was found between 'Yellow Krang' and 'Red Krang' (Table 1). 'Yellow Krang' and 'Red Krang' had more flowers per tree than two other check cultivars (Table 2). Analysis of the number of fruits per plant at 8 months showed that 'Yellow Krang' had consistently more fruits than the three check cultivars (Table 3). A study by Chaiyaboon and Janthasri (2013) found that papaya in Thailand flowers faster during the hot season in comparison to the rainy and the cool season. Therefore, differences in dates of flowering when planted in different places were found. Flowering was earliest in Khon Kaen, where the temperatures were higher during the season in comparison to Kalasin where fields were located at higher elevation (Table 1).

Our data shows only the mean number of flowers per plant when assessed at the $4^{\text {th }}$ month. Usually, when the temperature and air humidity are optimal, and when supplied with the proper nutrients, most cultivars of papaya will continue flowering as the plant matures, so the number of flowers at the 4th month is only a rough estimation of the potential of each cultivar. For this research, we recorded the number of fruits per plant at month 8 , so in some cases the number of fruits was higher than the initial number of flowers counted at month 4 th. Analysis of the number of fruits per plant at 8th month showed that 'Yellow Krang' had higher yield than 'Red Krang' and two other check cultivars (Table 3). Due to vegetation conditions and nutrition level, papaya plants in Kalasin Province had the highest yield. Nevertheless, 'Yellow Krang' and 'Red Krang' cultivars were the most productive and bore the most fruit in all four test areas (Table 3). 


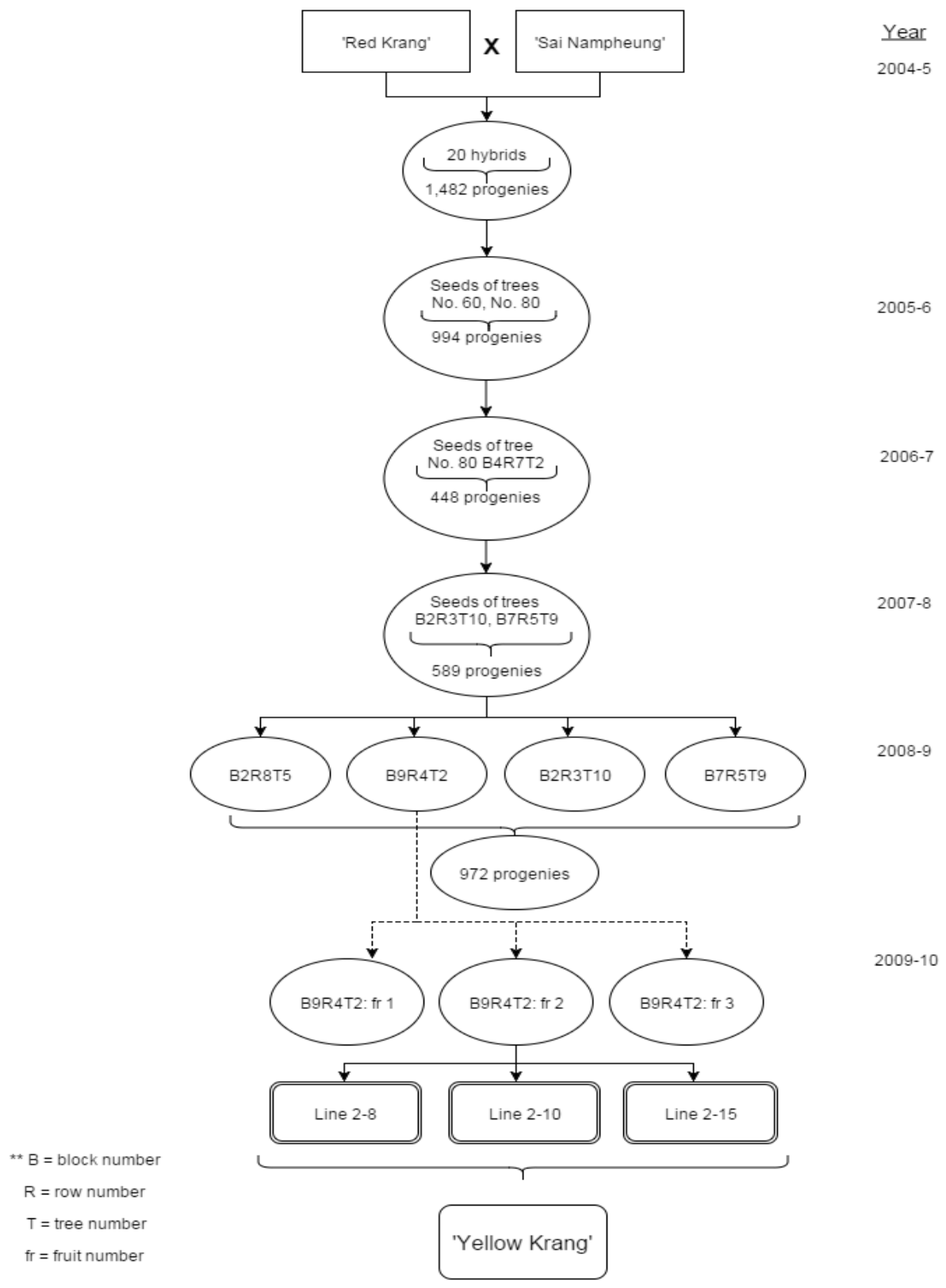

Fig. 1. Pedigree of 'Yellow Krang'

Table 1. Average number of days to first anthesis of 'Yellow Krang' papaya and three check cultivars observed in four test sites over three seasons (2013-2015), $\mathrm{n}=20$

\begin{tabular}{lcccc}
\hline \multirow{2}{*}{ Cultivar } & \multicolumn{4}{c}{ Test sites } \\
\cline { 2 - 5 } & Maha Sarakham & Khon Kaen & Kalasin & Roi Et \\
\hline Yellow Krang & $104.1 \mathrm{~b} *$ & $98.6 \mathrm{~b}$ & $111.4 \mathrm{~b}$ & $105.8 \mathrm{~b}$ \\
Red Krang & $129.3 \mathrm{ab}$ & $118.9 \mathrm{~b}$ & $127.7 \mathrm{~b}$ & $120.7 \mathrm{~b}$ \\
Khaeg Dum Gosum & $156.4 \mathrm{a}$ & $155.3 \mathrm{a}$ & $168.2 \mathrm{a}$ & $159.3 \mathrm{a}$ \\
Khaeg Nuan & $153.1 \mathrm{a}$ & $160.1 \mathrm{a}$ & $165.3 \mathrm{a}$ & $163.4 \mathrm{a}$ \\
CV\% & 11.2 & 3.5 & 3.1 & 7.9 \\
\hline
\end{tabular}

*Means followed by the same letter are not significantly different within columns at $\mathrm{p}=0.05$ according to LSD test. 


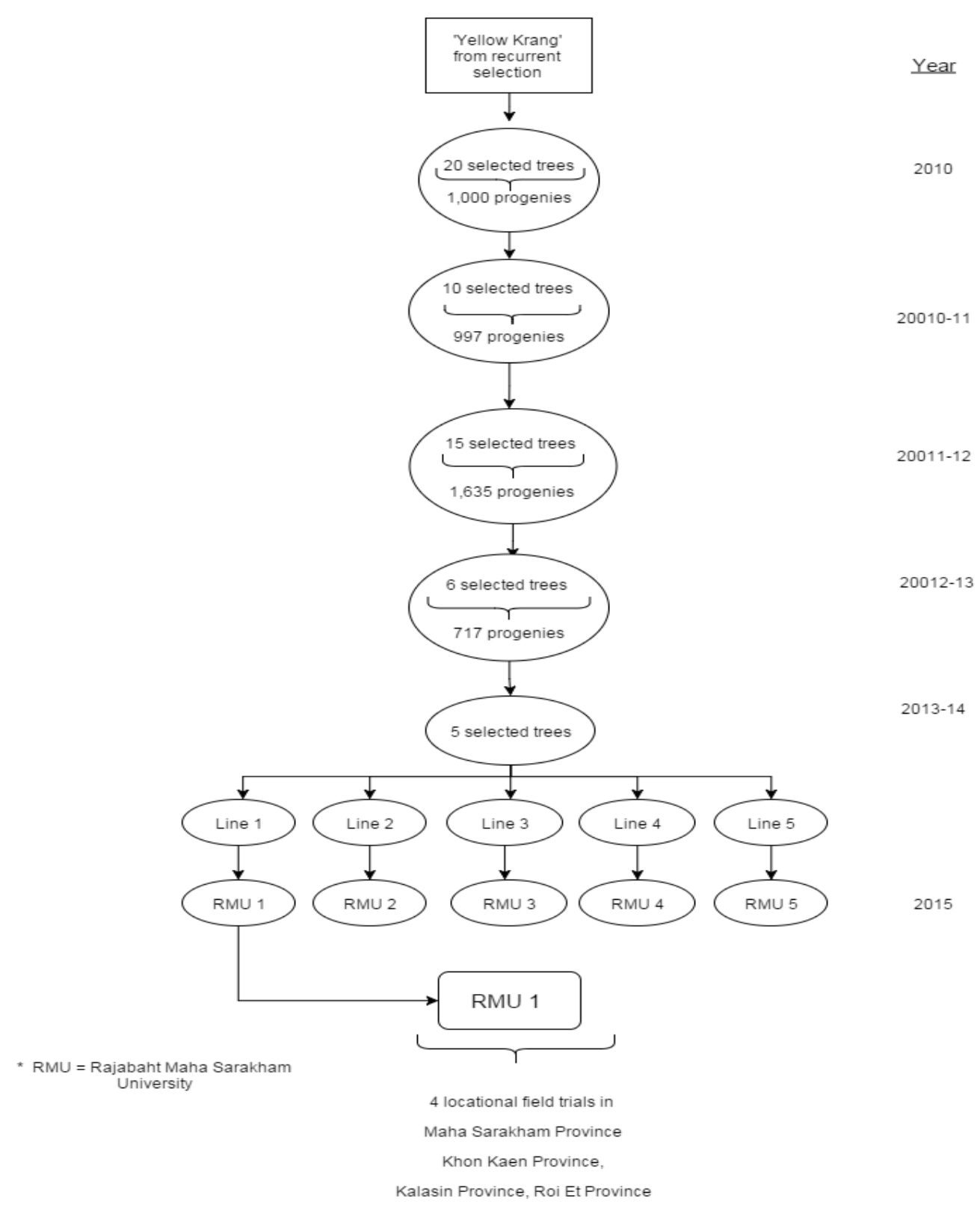

Fig. 2. Scheme to select papaya cultivar for unripe consumption by pure line selection across years 2010-2014

Table 2. Average number of flowers per tree at four months of 'Yellow Krang' papaya and three check cultivars observed in four test sites over three seasons (2013-2015), $\mathrm{n}=20$

\begin{tabular}{lcccr}
\hline \multirow{2}{*}{ Cultivar } & \multicolumn{4}{c}{ Test sites } \\
\cline { 2 - 5 } & Maha Sarakham & Khon Kaen & Kalasin & Roi Et \\
\hline Yellow Krang & $90.1 \mathrm{a}$ a & $118.7 \mathrm{a}$ & $96.4 \mathrm{a}$ & $95.4 \mathrm{a}$ \\
Red Krang & $112.1 \mathrm{a}$ & $139.4 \mathrm{a}$ & $110.0 \mathrm{a}$ & $112.6 \mathrm{a}$ \\
Khaeg Dum Gosum & $89.6 \mathrm{~b}$ & $88.3 \mathrm{~b}$ & $65.9 \mathrm{~b}$ & $74.4 \mathrm{~b}$ \\
Khaeg Nuan & $72.2 \mathrm{~b}$ & $79.1 \mathrm{~b}$ & $74.6 \mathrm{~b}$ & $62.7 \mathrm{~b}$ \\
CV\% & 3.8 & 12.9 & 8.8 & 5.1 \\
\hline
\end{tabular}

*See Table 1 
Table 3. Average number of fruits per tree at eight months of 'Yellow Krang' papaya and three check cultivars observed and 'Khaeg Nuan' in four test sites over three seasons (2013-2015), n = 20

\begin{tabular}{lcccc}
\hline \multirow{2}{*}{ Cultivar } & \multicolumn{4}{c}{ Test sites } \\
\cline { 2 - 5 } & Maha Sarakham & Khon Kaen & Kalasin & Roi Et \\
\hline Yellow Krang & $198.8 \mathrm{a}$ & $190.3 \mathrm{a}$ & $220.4 \mathrm{a}$ & $215.9 \mathrm{a}$ \\
Red Krang & $112.3 \mathrm{~b}$ & $116.4 \mathrm{~b}$ & $137.7 \mathrm{~b}$ & $126.8 \mathrm{~b}$ \\
Khaeg Dum Gosum & $56.5 \mathrm{c}$ & $79.6 \mathrm{c}$ & $72.3 \mathrm{c}$ & $88.3 \mathrm{c}$ \\
Khaeg Nuan & $74.3 \mathrm{c}$ & $80.5 \mathrm{c}$ & $85.7 \mathrm{c}$ & $70.4 \mathrm{c}$ \\
CV\% & 10.6 & 4.6 & 5.8 & 7.4 \\
\hline
\end{tabular}

*See Table 1

There were no statistically significant differences in mean fruit weight between the different cultivars in the four test areas. 'Yellow Krang' and 'Red Krang' cultivars had higher mean fresh weight per fruit than two other check cultivars (data not given). When comparing the fruit yield in four different places, 'Red Krang' was the most productive although not significantly different from 'Yellow Kang'. There were differences between plants grown in different places (Table 4). The highest yield was observed in Roi Et where plantation was surrounded by forests and the incidence of PRSV was much less than at the other test areas, where the fields were in wide open spaces.

\section{Unripe fruit quality}

Statistically significant differences were found in flesh thickness, flesh firmness, fruit cavity size and number of seeds per fruit among the 4 cultivars. 'Yellow Krang' and 'Red Krang' had thicker and firmer flesh compared to the other test cultivars (Tables $5 \& 6$ ). 'Red Krang' was found to have the largest mean fruit cavity compared to the other cultivars (data not shown).

\section{Incidence of PRSV}

There were statistically significant differences in the incidence of PRSV among the four cultivars and the four test areas (Table $7 \& 8$ ). The lowest percentage of plants with PRSV symptoms was recorded for 'Yellow Krang' followed by 'Red Krang'. The incidence of PRSV was lowest in Roi Et Province due to differences in the geography and environment mentioned above and also because the virus was not yet prevalent in this area. In addition, the mean incidence level of PRSV in 'Yellow Krang' was lower than of other cultivars $(9.4 \%$ trees with symptoms at the Roi Et test site, $27.4 \%$ at Kalasin, $29.5 \%$ at Khon Kaen and $33.1 \%$ at Maha Sarakham, compared to a range of $32.6 \%$ to $97.4 \%$ for the other cultivars). One major limitation of this research was that we did not use more advanced techniques such as DNA marker assisted breeding. For future studies, it would be valuable to make a genetic analysis of the 'Yellow Krang' cultivar compared to 'Red Krang' and 'Florida Tolerant', PRSVsusceptible cultivars in order to help determine the genetic mechanisms that underlie increased tolerance to PRSV.

Table 4. Average yield (kg/ha) of 'Yellow Krang' papaya and three check cultivars observed in four test sites over three seasons (2013-2015), $\mathrm{n}=20$

\begin{tabular}{lcccc}
\hline \multirow{2}{*}{ Cultivar } & \multicolumn{4}{c}{ Test sites } \\
\cline { 2 - 5 } & Maha Sarakham & Khon Kaen & Kalasin & Roi Et \\
\hline Yellow Krang & $110.3 \mathrm{~b}$ & $123.9 \mathrm{ab}$ & $157.7 \mathrm{a}$ & $146.4 \mathrm{a}$ \\
Red Krang & $147.6 \mathrm{a}$ & $145.3 \mathrm{a}$ & $158.7 \mathrm{a}$ & $171.5 \mathrm{a}$ \\
Khaeg Dum Gosum & $54.1 \mathrm{c}$ & $64.9 \mathrm{~b}$ & $47.7 \mathrm{~b}$ & $79.4 \mathrm{~b}$ \\
Khaeg Nuan & $61.9 \mathrm{c}$ & $60.1 \mathrm{~b}$ & $77.2 \mathrm{~b}$ & $86.9 \mathrm{~b}$ \\
CV\% & 3.9 & 5.3 & 12.7 & 10.7 \\
\hline
\end{tabular}

*See Table 1 
Table 5. Average mean flesh thickness (cm) of 'Yellow Krang' papaya and three check cultivars observed in four test sites over three seasons (2013-2015), $\mathrm{n}=20$

\begin{tabular}{lcccc}
\hline \multirow{2}{*}{ Cultivars } & \multicolumn{4}{c}{ Test sites } \\
\cline { 2 - 5 } & Maha Sarakham & Khon Kaen & Kalasin & Roi Et \\
\hline Yellow Krang & $2.3 \mathrm{a}$ & $2.5 \mathrm{a}$ & $2.5 \mathrm{a}$ & $2.3 \mathrm{a}$ \\
Red Krang & $2.1 \mathrm{a}$ & $2.0 \mathrm{a}$ & $1.9 \mathrm{~b}$ & $1.2 \mathrm{~b}$ \\
Khaeg Dum Gosum & $1.6 \mathrm{~b}$ & $1.7 \mathrm{~b}$ & $1.5 \mathrm{~b}$ & $0.9 \mathrm{~b}$ \\
KhaegNuan & $1.9 \mathrm{ab}$ & $1.7 \mathrm{~b}$ & $1.6 \mathrm{~b}$ & $1.6 \mathrm{~b}$ \\
CV\% & 18.1 & 9.2 & 8.1 & 4.4 \\
\hline
\end{tabular}

*See Table 1

Table 6. Average mean flesh firmness (Newton) of 'Yellow Krang' papaya and three check cultivars observed in four test sites over three seasons (2013-2015), $\mathrm{n}=20$

\begin{tabular}{lcccc}
\hline \multirow{2}{*}{ Cultivars } & \multicolumn{4}{c}{ Test sites } \\
\cline { 2 - 5 } & Maha Sarakham & Khon Kaen & Kalasin & Roi Et \\
\hline Yellow Krang & $6.5 \mathrm{a}$ & $7.5 \mathrm{a}$ & $7.2 \mathrm{a}$ & $7.4 \mathrm{a}$ \\
Red Krang & $7.3 \mathrm{a}$ & $6.4 \mathrm{a}$ & $6.9 \mathrm{a}$ & $7.0 \mathrm{a}$ \\
Khaeg Dum Gosum & $5.4 \mathrm{~b}$ & $6.8 \mathrm{a}$ & $5.9 \mathrm{~b}$ & $6.3 \mathrm{~b}$ \\
KhaegNuan & $5.1 \mathrm{~b}$ & $5.3 \mathrm{~b}$ & $6.8 \mathrm{~b}$ & $6.9 \mathrm{~b}$ \\
CV\% & 2.14 & 6.90 & 2.33 & 5.61 \\
\hline
\end{tabular}

*See Table 1

Table 7. Per cent incidence of Papaya Ringspot Virus in 'Yellow Krang' papaya and three check cultivars observed in four test sites over three seasons $(2013-2015), \mathrm{n}=20$

\begin{tabular}{lcccc}
\hline \multirow{2}{*}{ Cultivar } & \multicolumn{4}{c}{ Test sites } \\
\cline { 2 - 5 } & Maha Sarakham & Khon Kaen & Kalasin & Roi Et \\
\hline Yellow Krang & $33.1 \mathrm{c}$ & $29.5 \mathrm{c}$ & $27.4 \mathrm{c}$ & $9.4 \mathrm{c}$ \\
Red Krang & $61.5 \mathrm{~b}$ & $51.4 \mathrm{~b}$ & $32.6 \mathrm{c}$ & $44.8 \mathrm{~b}$ \\
Khaeg Dum Gosum & $80.5 \mathrm{a}$ & $87.5 \mathrm{a}$ & $72.2 \mathrm{~b}$ & $95.3 \mathrm{a}$ \\
KhaegNuan & $97.4 \mathrm{a}$ & $90.3 \mathrm{a}$ & $94.6 \mathrm{a}$ & $84.2 \mathrm{a}$ \\
CV\% & 3.9 & 4.4 & 4.1 & 7.0 \\
\hline
\end{tabular}

*See Table 1

Note: $\%$ disease incidence $=\frac{\text { Number of diseased trees } \times 100}{\text { Total number of trees per treatment }}$

Table 8. Level of infestation by Papaya Ringspot Virus (on 4-point scale) in 'Yellow Krang' papaya and three check cultivars observed in four test sites over three seasons (2013-2015), $\mathrm{n}=20$

\begin{tabular}{lcccc}
\hline \multirow{2}{*}{ Cultivar } & \multicolumn{4}{c}{ Test sites } \\
\cline { 2 - 5 } & Maha Sarakham & Khon Kaen & Kalasin & Roi Et \\
\hline Yellow Krang & $2.3 \mathrm{~b}$ & $2.9 \mathrm{~b}$ & $2.1 \mathrm{~b}$ & $2.0 \mathrm{~b}$ \\
Red Krang & $3.1 . \mathrm{ab}$ & $3.5 \mathrm{a}$ & $2.9 \mathrm{~b}$ & $2.5 \mathrm{~b}$ \\
Khaeg Dum Gosum & $3.8 \mathrm{a}$ & $3.6 \mathrm{a}$ & $3.8 \mathrm{a}$ & $3.1 \mathrm{a}$ \\
Khaeg Nuan & $3.9 \mathrm{a}$ & $3.9 \mathrm{a}$ & $4.0 \mathrm{a}$ & $3.6 \mathrm{a}$ \\
CV\% & 4.8 & 8.4 & 7.2 & 3.7 \\
\hline
\end{tabular}

*See Table 1 


\section{CONCLUSION}

A new papaya cultivar for unripe consumption selected for growing in Maha Sarakham Province condition and with tolerance to PRSV was developed by hybridizing 'Red Krang' cultivar, which has crispy flesh, with Sai Nampheung cultivar, which has smooth fruit shape and flesh that is fragrant and yellow when unripe. Breeding, selection and testing were carried out for 12 years, from 2004 to 2015, finally resulting in development of the Yellow Krang cultivar, which is appropriate for unripe consumption. The new cultivar was tested against three other cultivars at four test sites. It was found that 'Yellow Krang' is dwarf, with mean plant height of 110-150 cm, takes an average of 105 days to flower, produces an average of 100 flowers per tree at the $4^{\text {th }}$ month and an average of 206 fruits per plant per year of the average weight $1.2 \mathrm{~kg}$, with average flesh thickness of $2.4 \mathrm{~cm}$ and flesh firmness of 7.15 Newtons. The average yield is $134606 \mathrm{~kg}$ per hectare and the incidence of PRSV is $24.9 \%$. In addition, the new cultivar has other desirable characteristics. It is monoecious, the hermaphrodite flowers produce fruits with a long tapered shape. It is quick to flower and early bearing. Fruit for unripe consumption can be harvested in just 5 months after fruit set and the plant will continue producing fruits for 2 years. The fruit peel is smooth. Unripe fruits have a shelf life of about 20 days of about 20 days.

\section{Acknowledgements}

The authors would like to thank the Thailand Research Fund for funding and Mrs. Valerie Suwanseree for English language editing.

\section{REFERENCES}

Badillo V.M. 1983. Caricaceae. In: Harling G., Sparre B. (Eds.), Flora of Ecuador. Balogh Scientific Book, Illinois, pp. 27-47.

Baebprasert C. 1987. Development of the Pak Chong Papaya Cultivar. Research report of the School of Agriculture, Kasetsart University. (in Thai)

Busabakorakul S. 2000. Effect of temperature and humidity on variation in floral gender of perfect flowers of Mexican papaya during the hot season.
Bachelor's degree special problem research, Horticulture Department, School of Agriculture, Kasetsart University, $15 \mathrm{p}$. (in Thai)

Chaiyaboon W., Janthasri R. 2013. A comparison of the growth and production of 10 papaya lines in Maha Sarakham Province. Master's degree thesis, School of Agricultural Technology, Rajabhat Maha Sarakham University, 90 p. (in Thai with English abstract)

Department of Agriculture 1997. Proceedings of a seminar on papaya held at the Jaroen Thani Princess Hotel, Khon Kaen Province on 2-4 July 1997, 90 p. (in Thai)

Drew R. 2014. The use of non-transgenic technologies for the development of papaya ringspot virus resistance in Carica papaya. Acta Horticulturae 1022: 17-21. DOI: 10.17660/ActaHortic.2014.1022.2.

Janthasri R. 2004. A study of papaya tolerance to Papaya Ring Spot Virus in Ubon Ratchathani Province. Research report of the School of Agriculture, Ubon Ratchathani University, 20 p. (in Thai)

Janthasri R. 2005. Papaya. Course materials for a course on tropical fruit production of the Horticulture Department, School of Agriculture, Ubon Ratchathani University, 64 p. (in Thai)

Janthasri R., Janthasri K. 2005. Comparison of papaya cultivars' tolerance to Papaya Ring Spot Virus in Ubon Ratchathani Province. Ubon Ratchathani University Academic Journal 8(1): 8-19. (in Thai with English abstract)

Janthasri R. 2007. Commercial papaya. First edition. Ubol Ratchathani University Press, 80 p. (in Thai)

Janthasri R., Khumcha U., Katengam S. 2007. An analysis on DNA fingerprints of thirty papaya cultivars (Carica papaya L.), grown in Thailand with the use of Amplified Fragment Length Polymorphisms technique. Pakistan Journal of Biological Sciences 10(18): $\quad 3072-3078 . \quad$ DOI: 10.3923/pjbs.2007.3072.3078.

Janthasri R., Chokesawathanakij S., Arimatsu P., Chaiyaboon W., Setmo S. 2010. The situation of papaya production, growing, and processing in the central north-eastern region. Full report on the papaya research project. Thailand Research Fund., 98 p. (in Thai with English abstract)

Kim M.S., Moore P.H., Zee F., Fitch M.M.M., Steiger D.L., Manshardt R.M., et al. 2002. Genetic diversity of Carica papaya as revealed by AFLP Marker. Genome 45: 503-512. DOI: 10.1139/G02-012. 
Litz R.E., Conover R.A. 1981. Effect of sex type, season and other factors on in vitro establishment and culture of Carica papaya L. explants. Journal of the American Society for Horticultural Science 106: $792-794$.

Magoon C.E. 1980. Papaya: Fruit and Vegetable Facts and Pointers. United Fresh Fruit and Vegetable Association. North Washington at Madison, Alexandria Virginia, 8 p.

Prasartsee V. 2009. Papaya Ring Spot Virus and its prevention and control. Khon Kaen Hotricultural Experiment Station, Sisaket Horticultural Research Center, Horticultural Research Institute, Department of Agriculture. (in Thai)
Purcifull D.E., Ewardson J.R., Hiebert E., Gonsalves D. 1984. Papaya ringspot virus. CMI/AAB Descriptions of Plant Virus, no. 84, revised.

Sisaket Horticultural Research Center 1998. Selection of Khaeg Dum papaya. Annual research report, 1998. Aksornbundit Publishers, Bangkok. (in Thai)

Somsri S. 2014. Current status of papaya production in Thailand. Acta Horticulturae 1022: 31-45. DOI: 10.17660/ActaHortic.2014.1022.3.

Yimsawat T. 1992. Papaya. Course materials for a course on tropical fruit production of the Horticulture Department, Faculty of Agriculture, Khon Kaen University. (in Thai) 